\title{
Water level effect on herbaceous plant assemblages at an artificial reservoir-Lago Azul State Park, Southern Brazil
}

\author{
D. C. Souza ${ }^{a *}$, J. D. Ferreira ${ }^{a}$, P. A. A. Bueno ${ }^{a}$, L. Iwakura ${ }^{a}$, R. O. Bueno ${ }^{a}$ and J. B. Campiolo \\ áLaboratório de Ecologia, Universidade Tecnológica Federal do Paraná - UTFPR, Via Rosalina Maria dos Santos, \\ 1233, CP 271, CEP 87301-899, Campo Mourão, PR, Brazil \\ *e-mail: dcsouza@utfpr.edu.br
}

Received: January 17, 2015 - Accepted: May 20, 2015 - Distributed: November 30, 2015

(With 6 figures)

\begin{abstract}
This study presents the effect of water level variation on the assemblages of herbaceous species in Mourão I Reservoir, Lago Azul State Park, Southern Brazil. The structure and distribution of populations was examined in February (dry period) and April (rainy period), 2011, in two transects. These transects started at the forest edge towards the center of the lake. The end of the transect coincided with the end of the plants within the lake. On every two meters along of the transects we sampled a wooden square of $0.25 \mathrm{~m}^{2}$ for species biomass analysis. The macrophyte stand was composed entirely of emergent species. Considering the periods, most species were less frequent in the rainy period (April), but Ipomea ramosissima (Poir.) Choisy, Commelina nudiflora L., Eleocharis acuntagula (Roxb.) Schult. and Verbena litorales (Kunth.) had their frequency increased during this period, probably due to their resistance. The influence of flood as measured by the NMDS point out that both before and after the flood, there are plots with distinct compositions and biomass. The water level variation affects the dynamics of plant composition and structure in marginal areas of the Reservoir.
\end{abstract}

Keywords: water level, herbaceous, reservoir.

\section{O efeito do nível hidrométrico sobre a vegetação herbácea de um reservatório artificial no Sul do Brasil}

\begin{abstract}
Resumo
Este estudo apresenta o efeito da variação no nível hidrométrico do reservatório Mourão I, no Parque Estadual do Lago Azul, Paraná sobre a assembleia de espécies herbáceas na região de formação do reservatório. O estudo da estrutura e distribuição das populações foi realizado nos meses de fevereiro (seca) e abril (cheia) de 2011, para isto estabeleceu-se em pontos distintos duas transecções. As transecções começavam na bordada floresta em direção ao centro do lago. O fim da coleta na transecção acontecia quando acabavam as plantas dentro do lago. Ao longo das transecções a cada dois metros um quadrado de madeira com área de $0,25 \mathrm{~m}^{2}$ foi utilizado para amostrar as espécies, com coleta de biomassa. A maioria das espécies teve sua frequência reduzida durante a cheia (abril), porém Ipomea ramosissima (Poir.) Choisy, Commelina nudiflora L., Eleocharis acuntagula (Roxb.) Schult. e Verbena litorales (Kunth.) aumentaram sua frequência durante esse período. A influência da cheia medida pelo NMS indica que tanto antes da cheia quanto após a cheia existem parcelas com composições e biomassa típicas. A variação hidrométrica tem influência sobre a dinâmica da composição e estrutural vegetal nas áreas marginais do reservatório.
\end{abstract}

Palavras-chave: nível hidrométrico, herbáceas, reservatório.

\section{Introduction}

The operation of hydroelectric directly influences the dynamics of the ecotone formed on the banks of the reservoir, especially the populations of aquatic macrophytes (Thomaz and Bini, 2003). Some authors consider that human exploitation and seasonal variation in the water level can result in reduced biodiversity of aquatic macrophytes, thus modifying the whole ecosystem (Pott and Pott, 2003; Maltchik et al., 2004; Blom et al., 1996).
Deep changes occur in reservoirs due to retention of water, once dams significantly attenuate current flow, increasing the mean residence time of water (Nielsen and Chick, 1997). In backwater regions of reservoirs limnological conditions usually differ from the main channel as flow rates, average depth, chemical and biological varies (Camargo et al., 2003). The propagation of aquatic macrophytes are commonly observed in these environments, 
rooted species occupy littoral regions, where they find appropriate conditions for attachment and nutrition, free and floating species may occupy larger areas (French and Chambers, 1996).

Studies in Brazil showed that the period of growth and mortality of aquatic macrophytes are closely related to the variation of water level (Piedade et al., 1991; Junk and Piedade, 1993; Camargo and Esteves, 1996). Through monitoring, it were found that during flooding periods some species of aquatic macrophytes develop better, increase biomass, while other plant species undergo reduction, and develop in periods with lower water level (Neiff, 1975; François et al., 1989). According to Pompêo and Henry (1996), this alternance of growth periods between plants is possibly a strategy to minimize competition, because in response to changes, they develop several survival strategies.

In the region of Campo Mourão, Paraná State, there are numerous rivers with flooded areas covered with macrophytes. Among them, stands out the area of the Mourão I Reservoir, which was formed in 1964 by the flooding of the rivers Mourão in the municipality of Campo Mourão and Sem Passo in the municipality of Luiziana (IAP, 2005). The reservoir formation occurred in an undulated depression with favorable conditions for the development of aquatic vegetation.

The region has several protected lateral lakes and flooded areas that serve as refuge for many animal species, which find favorable sites for breeding, feeding, and shelter. Thus, knowledge of this vegetation under the influence of the power plant operating system proved important to identify local trophic relationships and establish management strategies for the conservation unit.

This study presents the effect of the variation in the water level of the Mourão I Reservoir, at the State Park Lago Azul, Paraná State, on the structure of assemblages of herbaceous species in the region of the reservoir.

\section{Material and Methods}

The State Park Lago Azul has about 1,749 ha, with its geographical center at $52^{\circ} 20^{\prime}$ longitude and $24^{\circ} 04^{\prime}$ latitude. This area is protected by Decree 3256 of June $30^{\text {th }}, 1997$ in order to preserve the reservoir of the Mourão Hydroelectric Power Plant, as well as its surroundings. The reservoir is formed by Mourão and Sem Passo rivers, with flooded area of approximately 1,270 ha.

The study area it's situated near the confluence of these two rivers in a large and flooded area with low current flow, which forms an open lake towards of the dam, being a protected place that favor the development of aquatic macrophytes and serve as refuge for several animal species.

The structure and distribution of populations was examined in February (dry period) and April (rainy period), 2011, in two transects. These transects started at the forest edge towards the center of the lake. The end of the collection along of the transect occurred when there were no macrophytes within the lake. Along transects, every two meters, a wooden square of $0.25 \mathrm{~m}^{2}$ was used to sample the species for biomass analysis (Westlake, 1965, 1971).

The collected biomass was stored in polyethylene bags and taken to laboratory. Species were identified and separated to dry in an air circulating oven at $60{ }^{\circ} \mathrm{C}$ for 48 hours. After drying, biomass was weighed in an analytical balance.

The structure of assemblages was evaluated by Pielou Evenness and Shannon diversity indices (Krebs, 1999) and by comparing species richness between sampling periods. Data were arranged in similarity matrices, calculated by the Bray-Curtis distance coefficient (Krebs, 1999), for cluster and NMDS (non-metric multidimensional scaling) analyses made in PAST software (Hammer et al., 2001).

\section{Results and Discussion}

Altogether, 46 morfospecies were identified. The vegetation assemblages stand was composed of aquatic macrophytes emergent and land herbaceous. This was not expected, once the lake is manly colonized by mixed banks of aquatic macrophytes, even though emergent species usually dominate these associations (Abdon et al., 1998; Souza et al., 2002). Probably the lack of floating or submerged species in this reservoir is due to large variation in water level, because it is a reservoir with water abstraction at the bottom of the dam. Considering seasons, most species were less frequent in the rainy period (April), but Ipomea ramosissima (Poir.) Choisy, Commelina nudiflora L., Eleocharis acuntagula (Roxb.) Schult. and Verbena litorales (Kunth.) increased their frequency during this period, probably due to their resistance, and even took advantage of abiotic factors of the site, often inappropriate for other species.

The Bray-Curtis Cluster analysis indicated the formation of two groups before the rainy period (February), consisting of plots 1-3 and 35-39 (Figure 1), and plots from the 24 are grouped near the wetter plots. This group reflects the characteristics of the environment; the first plots are closer to the forest and contain greater predominance of species less resistant to wet conditions like Pennisetum sp., P. guerkeana, B. dracunculifolia, T. cerastifolia, among others. These species expand their areas of colonization in drier periods and eventually reduce them in times of flood.

In turn, the flood works as an element of desestructuration of the landscape, breaking the hegemony and preventing dominance. In this way, in the cluster of April, although groups of the ends of transects persist, enhances the binding of the plots from 24 to 39 (Figure 2). Also in this period occurs the expansion of the colonization area of macrophytes, resulting in the emergence of new species and alternation in the frequency of other species, associated with changes in the water regime that favor some species, serving to maintain diversity (Combroux et al., 2001).

These reactions to the change in water level were reflected in the indices of Shannon and evenness. In general, the Shannon index was low, 1.36 in the dry period, and 1.46 in the rainy period. In a similar study, Pitelli and Pitelli (2008), reported a mean value of 2.70. Although 


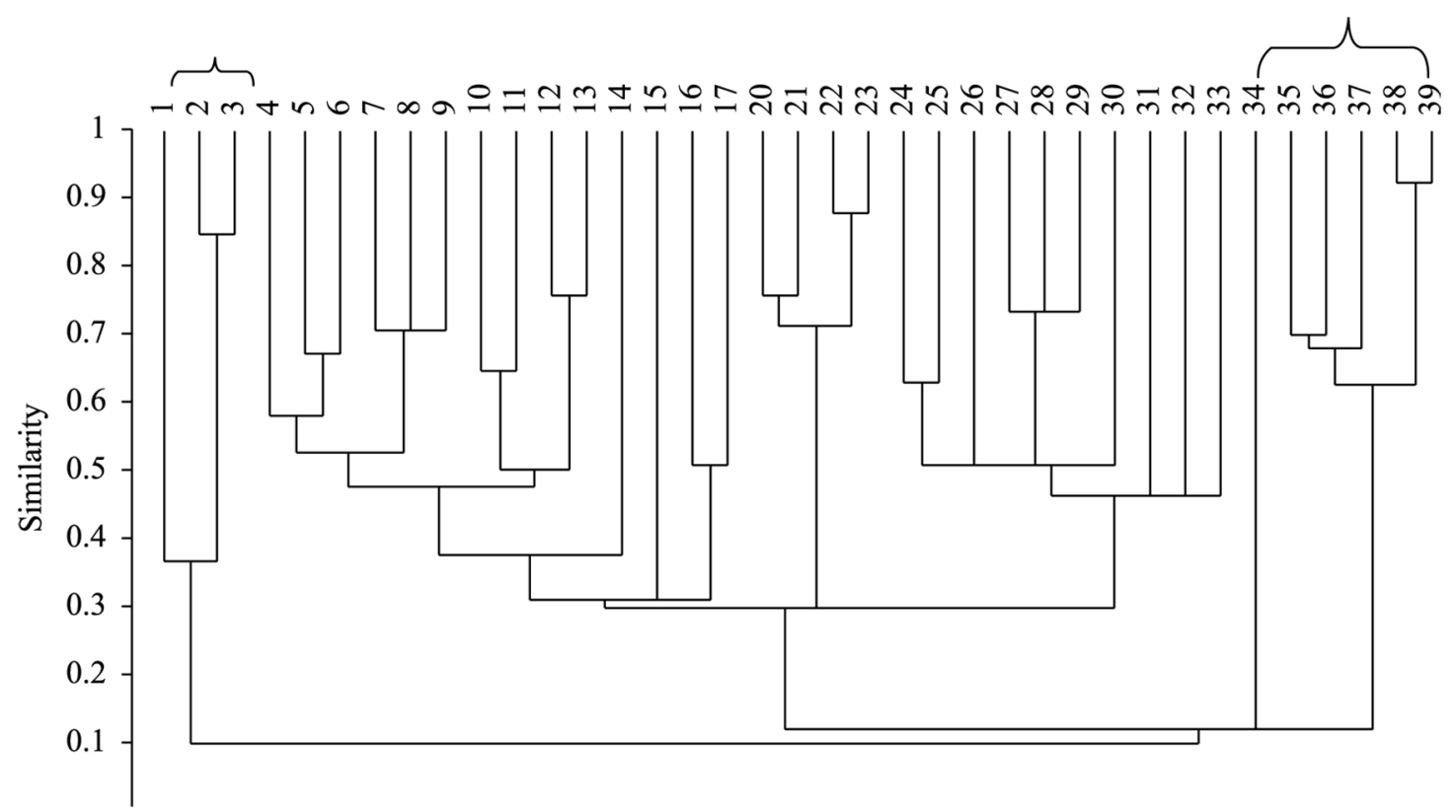

Figure 1. Cluster of similarity (Bray-Curtis) between the plots sorted according to distance from the forest, floristic composition and biomass, in February 2011 the Mourao I Reservoir, PR. "‘"Featured groups.

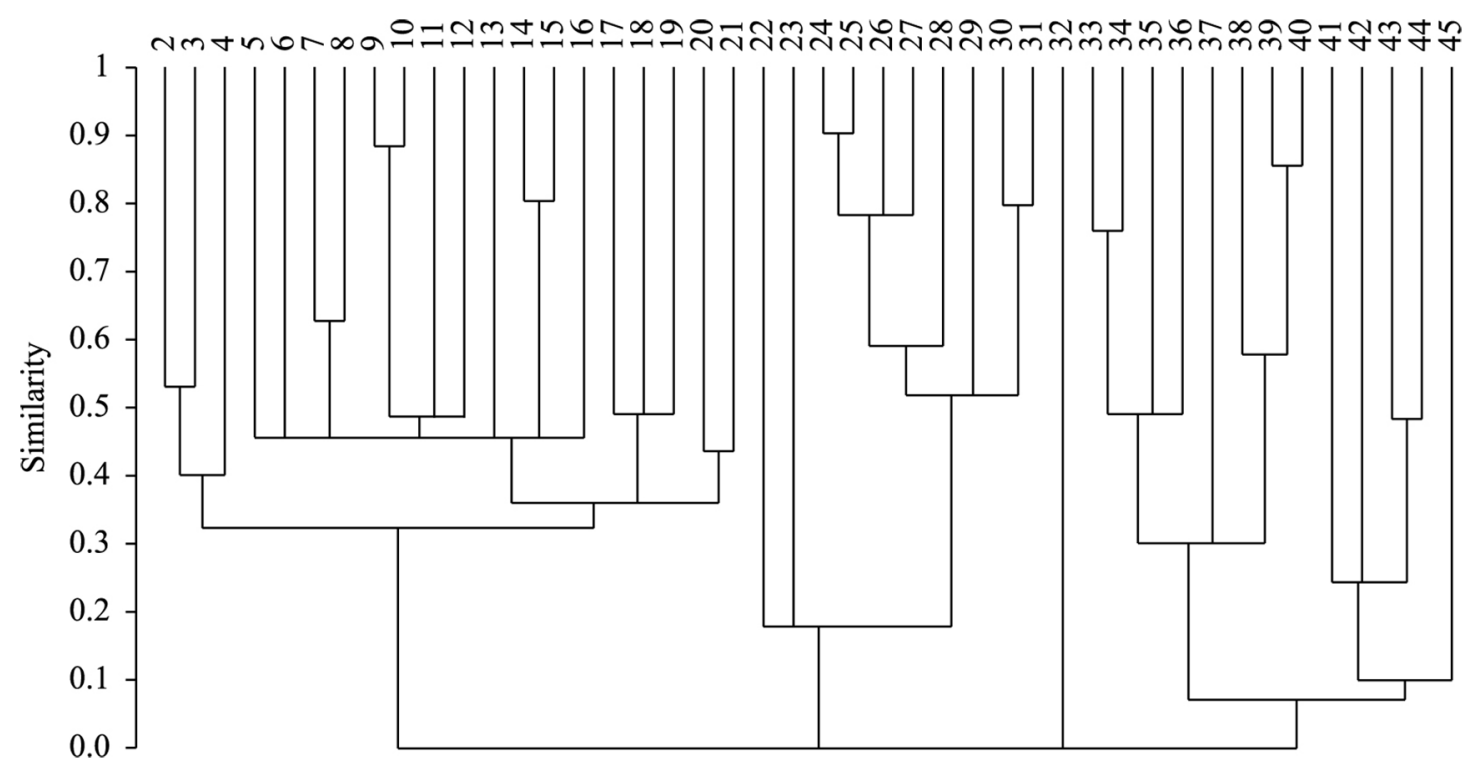

Figure 2. Cluster of similarity (Bray-Curtis) between the plots sorted according to distance from the forest, floristic composition and biomass, in April 2011 the Mourao I Reservoir, PR.

the Shannon had been low, it is possible to observe was an increase in richness with respect to density during the flooding. The Pielou evenness complements the statement about the effect of flood; its values were 0.83 and 0.90 in the respective periods, indicating no dominance of any species, regardless of the period.

The richness in the first transect during the rainy period increased from 18 to 23 species, but in the second transect only one species was added. Among the species that appeared with the flood, C. nudiflora and E. acutangula stand out with high frequencies in the transect 1 , and $R$. marisculus, in the transect 2. Other species, such as $A$. phyloxiroides (transect 1), Phyllantus sp. and Diodia sp. (transect 2) were not registered in the flood period. This dynamics of change of species observed is quite observed and is related to the events of shrinkage and expansion of land area that 
create new spaces and habitats (Tockner et al., 2000). Importantly, other factors also have influence on species richness and are associated with interactions between species (Crawley and Harral, 2001; Thomaz and Cunha, 2010) which change species composition and structure of assemblages over time.

Additionally, the same trend of responses to the flood was verified in the NMDS ordination analysis. Before the flood the plots show a wider range of composition and biomass, possibly because composition is under a greater influence of less aquatic species (Figure 3). Among them, $P$. rivulare, Bacharis sp. and T. cerastifolia were important for their biomass, and other less aquatic species standing out in biomass were P.acuminatum, Aeschinomene sp. and R. rugosa (Figure 4).

In relation to area/biomass ratio, in the transect 1 , total area was $9.75 \mathrm{~m}^{2}$ in February and $8 \mathrm{~m}^{2}$ in April. Biomass value reduced from $8717.4 \mathrm{~g} / \mathrm{m}^{2}$ to $7773.08 \mathrm{~g} / \mathrm{m}^{2}$, approximately $9 \%$. This change was not enough to cause system instability, since the NMDS analysis indicated large overlap of areas (Figure 3). Increasing the area available for colonization does not lead to an increase of biomass, which is explained by the fact that the destabilization caused by flood on the assemblages increases species richness (Casanova and Brock, 1996), but also decreases the coverage area of species less adapted to environmental changes (Engelhardt and Ritchie, 2001), reducing their biomass in this period.

On the other hand, the influence of flood appears to be greater in the transect 2, as measured by the NMDS, since the area overlap is lower, and the inclusion of plots is greater, pointing out that both before and after the flood, there are plots with distinct compositions and biomass (Figure 5).

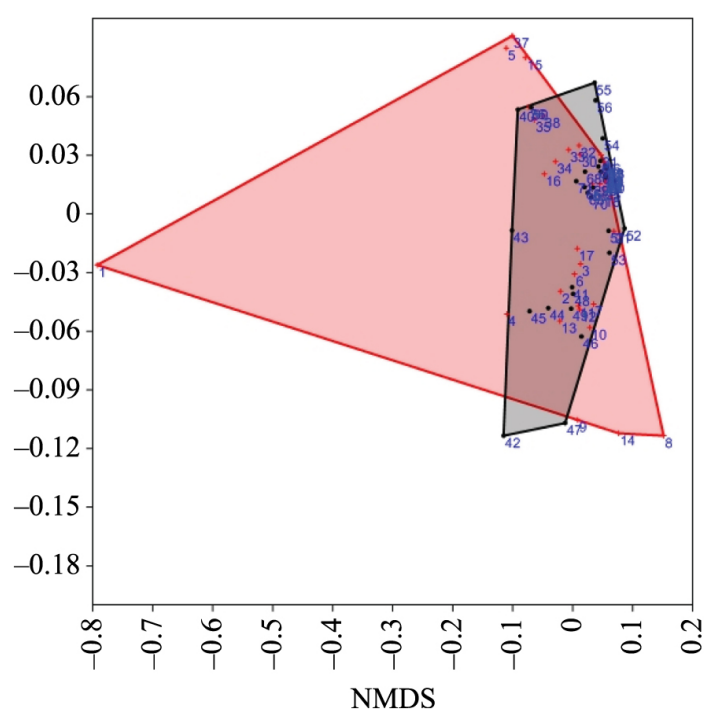

Figure 3. Cluster analysis NMDS (non- metric multidimensional scaling) with the biomass and floristic composition plots in order of distance from the forest, in February 2011 the reservoir Mourao I, PR.
In this transect, the area/biomass ratio was different from that observed in the first transect. There was a significant elevation in the number of samples with the total area growing from $9.75 \mathrm{~m}^{2}$ to $11.25 \mathrm{~m}^{2}$. The effect was opposite in relation to biomass, as seen in the transect one (1), which increased from $10329.84 \mathrm{~g} / \mathrm{m}^{2}$ to $10299.8 \mathrm{~g} / \mathrm{m}^{2}$, in February and April, respectively.

In the transect 2, P. acuminatum showed a biomass increase above $130 \%$, while species with more terrestrial characteristics presented reductions, for instance the $46 \%$ reduction of Baccharis sp. (Figure 6). Some species in the transect 1, like Aeschynomene sp. And T. cerastifolia, after the water level increase, exhibited an increase of over $150 \%$ in biomass per area, whereas in the transect 2 they showed a biomass reduction, under the same conditions. Poaceae was the dominant group in both transects, with the highest biomass per area among the species recorded.

The different response of species is associated with the distinct successional stages of the habitats in the lake, which are important in maintaining the diversity in
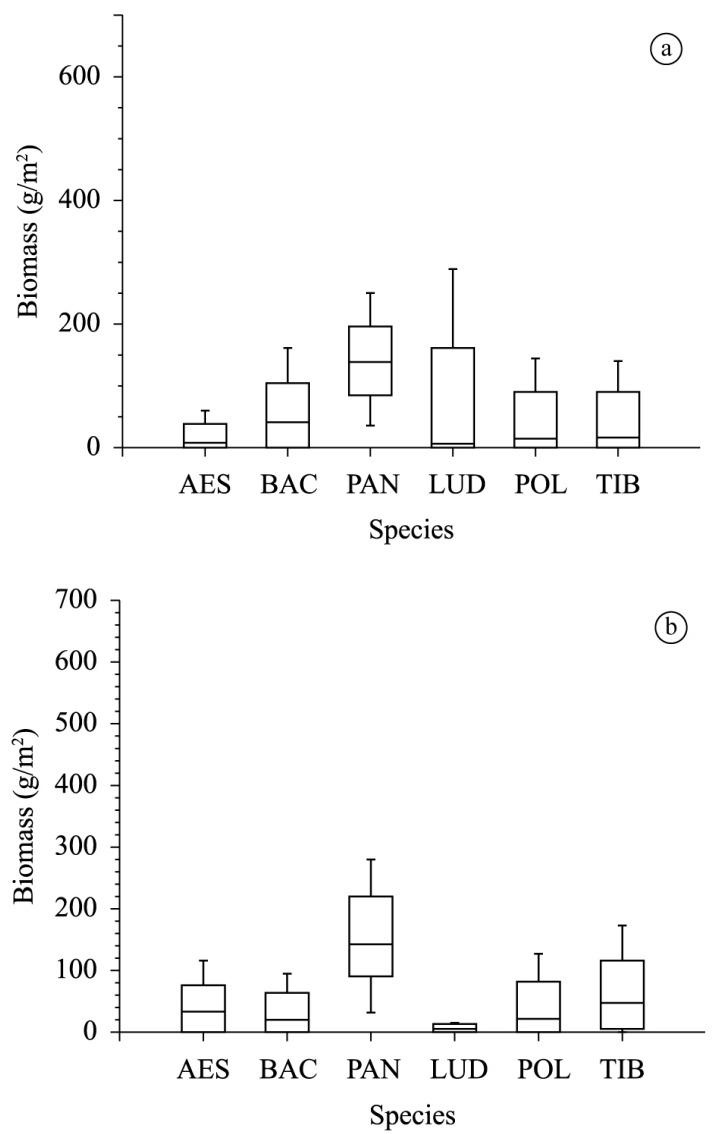

Figure 4. Values of biomass of the species most transection February 1 (a) and April (b) in the reservoir Mourao I, in Blue Lake State Park, PR. AES - Aeschinomene sp; BAC - Bacharis dracunculifolia; PAN - Panicum rivulare; LUD - Ludwigia octovalvis; POL - Polygonum acuminatum; TIB - Tibouchinia cerastifolia . 


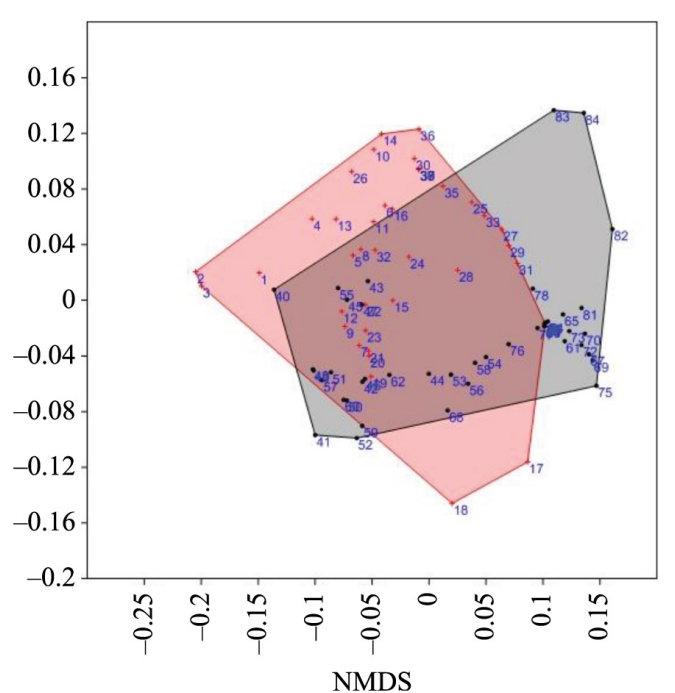

Figure 5. Cluster analysis NMDS (non- metric multidimensional scaling) with the biomass and floristic composition plots in order of distance from the forest, in April 2011 the Mourao I Reservoir, PR.
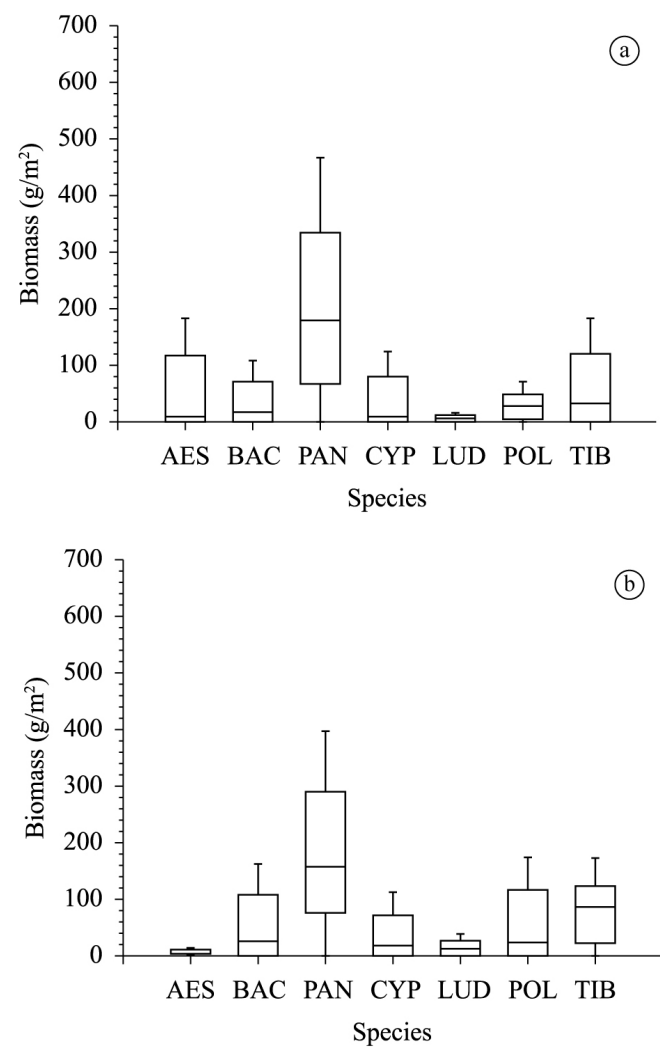

Figure 6. Values of biomass of the species most transect 2 in February 1 (a) and April (b) in the reservoir Mourao I, in Blue Lake State Park, PR. AES - Aeschinomene; $\mathrm{BAC}$ - Bacharis dracunculifolia; PAN - Panicum rivulare; CYP - Rhynchospora rugosa; LUD - Ludwigia octovalvis; POL - Polygonum acuminatum; TIB - Tibouchinia cerastifolia. floodplain environments (Ward, 1998; Pott and Pott, 2003). Considering that aquatic macrophytes exert an important role in structuring habitats, alteration in assemblage due to changes in vegetation composition could extend to alteration in biotic relationships among species (Pearson, 2009; Bickel and Closs, 2008). Although modified many years ago, this environment preserves, at least in marginal lakes, some characteristics of the ancient floodplain.

\section{Conclusion}

The water level variation affects the dynamics of plant composition and structure in marginal areas of the Mourão I Reservoir. Flood events ensure the survival of aquatic species preventing the dominance of terrestrial species. Therefore, to assure the preservation of these environments, it is important to avoid prolonged periods of low water in the reservoir.

\section{Acknowledgements}

The authors are especially thankful to Instituto Ambiental do Paraná through space in search and Fundação Araucária for scientific initiation.

\section{References}

ABDON, M.M., POTT, V.J. and SILVA, J.S.V., 1998. Avaliação da cobertura por plantas aquáticas em lagoas da sub-região da Nhecolândia no Pantanal por meio de dados Landsat e Spot. Pesquisa Agropecuária Brasileira, vol. 33, pp. 1675-1681.

BICKEL, T.O. and CLOSS, G.P., 2008. Fish distribution and diet in relation to the invasive macrophyte Lagarosiphon majorin the littoral zone of Lake Dunstan, New Zealand. Ecology of FreshwaterFish, vol. 17, no. 1, pp. 10-19.

BLOM, C.W.P.M., VISSER, E.J.M. and VOESENEK, L.A.C.J., 1996. Flooding the survival strategies of plants. In: C.W.P.M. BLOM. Flooding stress and tolerance of plants. Oxford: Ecology and Evolution. 295 p.

CAMARGO, A.F.M. and ESTEVES, F.A., 1996. Influence of water level variation on biomass and chemical composition of the aquatic macrophyte Eichhornia azurea (Kunth) in an oxbow lake of the Rio Mogi- Guaçu (São Paulo, Brazil). Archiv für Hydrobiologie, vol. 135, no. 3, pp. 423-432.

CAMARGO, A.F.M., PEZZATO, M.M. and HENRY-SILVA, G.G., 2003. Fatores limitantes à produção primária de macrófitas aquáticas. In: S.M. THOMAZ and L.M. BINI, eds. Ecologia e manejo de macrófitas aquáticas. Maringá: EDUEM, pp. 59-83.

CASANOVA, M.T. and BROCK, M.A., 1996. Can oospore germination patterns explain charophyte distribution in permanent and temporary wetlands? Aquatic Botany, vol. 54, no. 4, pp. 97312. http://dx.doi.org/10.1016/0304-3770(96)01032-7.

COMBROUX, I., BORNETTE, G., WILLBY, N.J. and AMOROS, C., 2001. Regenerative strategies of aquatic plants in disturbed habitats: the role of the propagule bank. Archiv für Hydrobiologie, vol. 2, no. 152, pp. 215-235.

CRAWLEY, M.J. and HARRAL, J.E., 2001. Scale dependence in plant biodiversity. Science, vol. 291, no. 5505, pp. 864-868. http://dx.doi.org/10.1126/science.291.5505.864. PMid:11157164. 
ENGELHARDT, K.A.M. and RITCHIE, M.E., 2001. Effects of macrophyte species richness on wetland ecosystem functioning and services. Nature, vol. 411, no. 6838, pp. 687-689. http:// dx.doi.org/10.1038/35079573. PMid:11395769.

FRANÇOIS, J., RIVAS, A. and COMPÈRE, R., 1989. Le pâturage semi-aquatique à Echinochloa stagnina (RETZ.) P.BEAUV. Etude approfondie de la plante "bourgou" et des bourgoutières situées en zone lacustre Du Mali. Bulletin des Recherches Agronomiques de Gembloux, vol. 2, no. 24, pp. 145-189.

FRENCH, T.D. and CHAMBERS, P.A., 1996. Habitat partitioning in riverine macrophyte communities. Freshwater Biology, vol. 36, no. 3, pp. 509-520. http://dx.doi.org/10.1046/j.13652427.1996.00105.x.

HAMMER, O., HARPER, D.A.T. and RIAN, P.D., 2001. Past: palaeonthological statistics software package for education and data analysis. Palaeontologia Electronica, vol. 4, no. 1, pp. 1-9.

INSTITUTO AMBIENTAL DO PARANÁ - IAP. Diretoria de Biodiversidade e Áreas Protegidas - DIBAP, 2005. Plano de Manejo Parque Estadual Lago Azul. Curitiba. 200 p.

JUNK, W.J. and PIEDADE, M.T.F., 1993. Biomass and primaryproduction of herbaceous plant communities in the Amazon floodplain. Hydrobiologia, vol. 263, no. 3, pp. 155-162. http:// dx.doi.org/10.1007/BF00006266.

KREBS, C.J., 1999. Ecological methodology. 2nd ed. California: Addison-Wesley Educational Publishers. $636 \mathrm{p}$.

MALTCHIK, L., ROLON, A.S., GUADAGNIN, D.L. and STENERT, C., 2004. Wetlands of Rio Grande do Sul, Brazil: a classification with emphasis on plant communities. Acta Limnologica Brasiliensia, vol. 2, no. 16, pp. 137-151.

NEIFF, J.J., 1975. Fluctuaciones anuales em La composition fitocenotica y biomassa de lahidrofitiaen lagunas islenas del Paraná Medio. Ecosur, vol. 4, no. 2, pp. 153-183.

NIELSEN, D.L. and CHICK, A.J., 1997. Flood-mediated in aquatic macrophyte community structure. Marine and Freshwater Research, vol. 48, no. 2, pp. 153-157. http://dx.doi.org/10.1071/MF96090.

PEARSON, D.E., 2009. Invasive plant architecture alters trophic interactions by changing predator abundance and behavior. Oecologia, vol. 159, no. 3, pp. 549-558. http://dx.doi.org/10.1007/ s00442-008-1241-5. PMid:19082630.

PIEDADE, M.T.F., JUNK, W.J. and LONG, S.P., 1991. The productivity of the $\mathrm{C} 4$ grass Echinochloa polystachya on the
Amazon floodplain. Ecology, vol. 4, no. 72, pp. 1456-1463. http://dx.doi.org/10.2307/1941118.

PITELLI, R.A. and PITELLI, R.L.C.M., 2008. Controle biológico de plantas daninhas na América Latina. In: S.B. ALVES and R.B. LOPES, eds. Controle microbiano de pragas na América Latina. Piracicaba: FEALQ, vol. 1, pp. 333-350.

POMPÊO, M.L.M. and HENRY, R., 1996. Variação sazonal dos teores de N e P no sedimento do rio Paranapanema (zona de desembocadura na represa de Jurumirim, SP). In: Anais do I Simpósio de Ciências da engenharia Ambiental, III Simpósio do Curso de Ciências da Engenharia Ambiental, 1996, São Carlos. São Carlos: CRHEA/EESC/USP, pp. 135-137.

POTT, V.J. and POTT, A., 2003. Dinâmica da vegetação aquática do Pantanal. In: S.M. THOMAZ and L.M. BINI, eds. Ecologia e manejo de macrófitas aquáticas. Maringá: EDUEM, pp. 145-162.

SOUZA, D.C., THOMAZ, S.M. and BINI, L.M., 2002. Species richness and beta-diversity of aquatic macrophytes assemblanges in three floodplain lagoons: evaluating the effects of sampling size and depth gradients. Amazoniana, vol. XVII, no. 1-2, pp. 213-225.

THOMAZ, S.M. and BINI, L.M., 2003. Ecologia e manejo de macrófitas aquáticas. Maringá: EDUEM, pp. 243-260.

THOMAZ, S.M. and CUNHA, E.R., 2010. The role of macrophytes in habitat structuring in aquatic ecosystems: methods of measurement, causes and consequences on animal assemblages' composition and biodiversity. Acta Limnologica Brasiliensia, vol. 22, no. 2, pp. 218-236. http://dx.doi.org/10.4322/actalb.02202011.

TOCKNER, K., MALARD, F. and WARD, J.V., 2000. An extension of the flood pulse concept. Hydrological Processes, vol. 14, no. 16-17, pp. 2861-2883. http://dx.doi.org/10.1002/10991085(200011/12)14:16/17<2861::AID-HYP124>3.0.CO;2-F.

WARD, J.V., 1998. A running water perspective of ecotones, boundaries, and connectivity. Verhandlungen des Internationalen Verein Limnologie, vol. 26, pp. 1165-1168.

WESTLAKE, D. F., 1965. Some basic data for investigations of the productivity of aquatic macrophytes. Memorie del línstituto di Idrobiologia Dott Marco de Marchi, vol. 18, pp. 229-248.

WESTLAKE, D.F., 1971. Macrophytes. In: R.A. VOLLENVEIDER. A manual of methods for measuring primary production in aquatic environments. Oxford: Blackwell Scientific Publication, pp. 2532. I.B.P. Handbook, no. 12. 